\title{
Genotyping single-nucleotide polymorphism CYP2C19*2, pharmacodynamic evaluation of high on-clopidogrel treatment platelet reactivity and the cardiologist
}

\author{
Genotipificación del polimorfismo de nucleótido simple CYP2C19*2, evaluación \\ farmacodinámica de la alta reactividad plaquetaria en tratamiento con clopidogrel \\ y el cardiólogo
}

\author{
Carlos F. Barrera-Ramírez ${ }^{*}$, Luis R. Pineda-Pompa ${ }^{2}$, Hermes llárraza-Lomeliß ${ }^{3}$ and Daniel Lira-Lozano ${ }^{4}$ \\ ${ }^{1}$ Hospital Medical Teaching, Hospital Universitario de Saltillo; ${ }^{2}$ Cardiovascular Division, Centro Hospitalario La Concepción. Saltillo, Coahuila; \\ ${ }^{3}$ Cardiac Rehabilitation and Physical Medicine, Instituto Nacional de Cardiología "Ignacio Chávez", Mexico City; ${ }^{4}$ Internal Medicine Service. Hospital \\ Universitario de Saltillo, Coahuila. México
}

Sir, we have read with interest Cedillo-Salazar et al. report ${ }^{1}$ and we believe pertinent make some comments.

Effectiveness of clopidogrel depends on its conversion to an active metabolite by CYP2C19 enzymes through two different metabolic set-ps. Individuals who carry one or two loss-of-function alleles (LOF) of the CYP2C19*2 - heterozygous or homozygous single-nucleotide polymorphism (SNP) - are associated with an intermediate or poor metabolism for clopidogrel, respectively ${ }^{2}$.

The prevalence of SNP CYP2C19 has an ethnic expression, $2 \%$ of Caucasians, $4 \%$ of African-Americans, and $14 \%$ of Chinese are CYP2C $19^{*} 2 /{ }^{*} 2$ carriers $^{2}$, in Mexicans, the prevalence of CYP2C19 in not well established. In Mexico, there are two main populations: native groups (Amerindians) and mestizos the result of post-Columbian admixture ${ }^{3}$. Mexican Amerindians are geographically located mainly in the center and southeast of the country ${ }^{3}$. Salazar-Flores et al. ${ }^{3}$ reported CYP2C $19{ }^{*} 2 /{ }^{*} 2$ frequency of $10 \%$ in Tarahumaras, $1.4 \%$ in mestizos and $0 \%$ in Purepechas, Tojolabales, Tzotziles y Tzetzales. CYP2C19*1/*2 is absent in Tzetzales and ranging from $6.6 \%$ to $40.5 \%$ in the other groups. León-Moreno et al. ${ }^{4}$ reported ${ }^{*} 2 /{ }^{*} 2$ genotype present only in North Lacandons in $2-2.7 \%$ and ${ }^{*} 1 /{ }^{*} 2$ ranging from $12 \%$ to $33 \%$.

We previously reported ${ }^{5} 109$ patients with acute coronary syndrome (ACS) treated with percutaneous coronary intervention $(\mathrm{PCl})$, from Saltillo and Puebla genotype frequency CYP2C $19^{*} 2 /{ }^{*} 2$ of $0.92 \%$, and $\mathrm{CY}$ P2C19 ${ }^{*} 1 /{ }^{*} 2$ of $17.4 \%{ }^{5}$. In contrast, Viveros et al. ${ }^{6}$ in Morelia in $90 \mathrm{PCl}$ patients reported CYP2C19*2/*2 frequency of $3.9 \%$ and CYP2C19 ${ }^{*} 1 /{ }^{*} 2$ of $17 \%$. Cedillo-Salazar informed CYP2C19*2/*2 frequency of $3.9 \%$ and $21.6 \%$ for $\mathrm{CYP} 2 \mathrm{C} 19{ }^{*} 1 /{ }^{*} 21$. These findings reinforce the concept of intrapopulation variation found in Mexico and the possible real and practical non-theoretical clinical impact.

Respect to the pharmacodynamic evaluation of the clopidogrel response, the authors divided patients arbitrarily into three groups and use the term "clopidogrel resistance"1. This term should be used if we employ a laboratory technique that detects the activity of the target receptor before and after the administration of the specific
Correspondence:

${ }^{*}$ Carlos F. Barrera-Ramírez

E-mail: carlosfbarrera@yahoo.com
Available online: $23-12-2020$

Arch Cardiol Mex. 2020;90(4):503-504 www.archivoscardiologia.com 2604-7063 / @ 2020 Instituto Nacional de Cardiología Ignacio Chávez. Published by Permanyer. This is an open access article under the CC BY-NC-ND license (http://creativecommons.org/licenses/by-nc-nd/4.0/). 
antiplatelet agent. Therefore, the absolute level of platelet reactivity during treatment, that is, "high on-treatment platelet reactivity" (HTPR) has been proposed as a better measure of thrombotic risk than responsiveness to clopidogrel ${ }^{7}$. The link between HTPR and ischemic or bleed events is well established ${ }^{7,8}$ and is accepted a therapeutic window using VerifyNow, with cutoff point for ischemic events >208 $\mathrm{PRU}^{7}$ and $<85 \mathrm{PRU}$ for hemorrhages ${ }^{7}$.

The potential benefits of genotyping are remarkable in ACS/PCI patients because LOF allele carriers can be identified, and alternative antiplatelet strategy can be instituted ${ }^{9,10}$.

Currently, there is conflicting evidence in regard to the use both, platelet function tests and CYP2C19 genotyping, but it is generally accepted that its use should be individualized in those patients at high risk and not routinely.

\section{Funding}

The present investigation has not received any specific scholarship from public, commercial, or non-profit agencies.

\section{Conflicts of interest}

The authors declare no conflicts of interest.

\section{Ethical disclosures}

Protection of human and animal subjects. The authors declare that no experiments were performed on humans or animals for this study.
Confidentiality of data. The authors declare that no patient data appear in this article.

Right to privacy and informed consent. The authors declare that no patient data appear in this article.

\section{References}

1. Cedillo-Salazar F, Martínez-Jacobo L, Pérez-Páramo Y, Cerda-Flores R, Martínez LE, Jaime-Pérez JC. Association of CYP2C19*2 polymorphism with clopidogrel resistance among patients with high cardiovascular risk in Northeastern Mexico. Arch Cardiol Mex. 2019;89:324-9.

2. Dean L. Clopidogrel therapy and CYP2C19 genotype. In: Medical Genetics Summaries. Bethesda (MD): National Center for Biotechnology Information; 2012.

3. Salazar-Flores J, Torres-Reyes LA, Martínez-Cortés G, Rubi-Castellanos R, Sosa-Macías M, Muñoz-Valle JF, et al. Distribution of CYP2D6 and CYP2C19 polymorphisms associated with poor metabolizer phenotype in five Amerindian groups and Western Mestizos from Mexico. Genet Test Mol Biomarkers. 2012;16:1098-104.

4. León-Moreno LC, Saldaña-Cruz AM, Sánchez-Corona J, Mendoza-Carrera F García-Zapién AG, Revilla-Monsalve C, et al. Distribution of potential risk alleles and haplotypes of the CYP2C9 and CYP2C19 genes in Mexican native populations: a comparative study among Amerindian populations. Meta Gene. 2019:20:100565.

5. Barrera-Ramírez CF, Pérez-Alva JC, Villegas-Torres B, Pineda-Pompa R, Uriel $P$, Juilo $C$, et al. Genotipificación del polimorfismo de nucleótido simple CYP2C19 en pacientes mexicanos con síndrome isquémico coronario agudo. Registro GNOMOS. Rev Mex Cardiol. 2014;25:3-40.

6. Viveros ME, Areán C, Gutiérrez S, Vázquez S, Cardiel MH, Taboada A, et al. Evaluación de la variabilidad en la respuesta a clopidogrel e identificación del polimorfismo CYP2C19 en pacientes mexicanos. Arch Cardiol Mex. 2016;86:297-304

7. Tantry US, Bonello L, Aradi D, Price MJ, Jeong Y, Angiolillo DJ, et al Consensus and update on the definition of on-treatment platelet reactivity to adenosine diphosphate associated with ischemia and bleeding. J Am Coll Cardiol. 2013;62:2261-73.

8. Bonello L, Tantry US, Marcucci R, Blindt R, et al. Consensus and future directions on the definition of high on-treatment platelet reactivity to adenosine diphosphate. J Am Coll Cardiol. 2010;56:919-33.

9. Cavallari LH, Lee CR, Beitelshees AL, Cooper-DeHoff RM, Duarte JD, Voora D, et al. Multisite investigation of outcomes with implementation of cyp2c19 genotype-guided antiplatelet therapy after percutaneous coronary intervention. JACC Cardiovasc Interv. 2018;11:181-91.

10. Claassens DM, Vos GJ, Bergmeijer TO, Hermanides RS, Van't Hof AW, Harst $P$, et al. A genotype-guided strategy for oral $P_{2} Y_{12}$ inhibitors in primary PCI. N Engl J Med. 2019;381:1621-31. 